\title{
Mixed Methods Research: A New Paradigm?
}

\author{
Uvie Igun
}

\section{Introduction}

In the paradigm war, brilliantly and summarily captured by Wright (1975), purists took their positions behind two major epistemological logics. The first is positivism which held that knowledge or all that can legitimately be accepted as knowledge, must be capable of being captured and expressed in terms and concepts that refer in an immediate way to reality or aspects of reality that are directly apprehendable by the senses and in a way that is open to public inspection by any observer. The logic of this is to seek and admit only objective directly measurable and quantifiable data and reject subjective data as inadmissible. According to him, producing explanations is the aim of positivists purists.

The second epistemological logic which grew out of hermeneutics, is known as interpretivism. Its logic is that social phenomena are the purposeful acts of men and women in interaction. Social scientists must therefore aim to produce understandings of them by analysing them within the context of purposes, meanings and intentions and justifications within which they are produced and reproduced. Their aim is to produce understanding of actions (Wright, 1975). The logic is that qualitative and subjective data are sought, admitted and treated as fundamental. Thus the paradigm war raged and researchers stuck to their allegiance to quantitative or qualitative methods.

Many scholars in the past exemplified this Puritanism. On the one side are those who argued that any research where there has been no mathematical or statistical analysis, is no research at all. To them, such cannot be called research but essay writing. On the other side, are those who pointed out that most statistical analyses in the social sciences tend to be vacous and without meaning. They usually added that the most profound works in the social sciences are not statistical.

It is however pointed out, that within the period when this war raged the fiercest, there were considerable numbers of scholars and researchers who accommodated the opposing'paradigms, albeit, very uncomfortably, within their research. The paradigm war has now been replaced by the rise of mixed methods research. We can now, with some justification, call the present, the age of mixed method research.

\section{Annals of the Social Science Academy of Nigeria, No 20, 2015}


The argument which underpines the rise of mixed method research is that it is better and more fruitful for applied social science research particularly development research, for methodological Puritanism to give way for methodological pragmatism. It is for example argued that mixed method ${ }^{\wedge}$ research can:

$>$ increase the accuracy of data;

provide a more complete presentation of the phenomenon under study, than would be yielded by a single paradigm approach (Cohen, Manion and Morrison, 2011).

The products of such research will tend thereby to overcome the weaknesses and biases of single paradigm research.

\section{Multi-methodological Research}

Before this period of the rise of mixed methods, there has been multi-methodological research. There were three main types of designs:

$>$ Quantitative with qualitative supplementation;

$>$ Qualitative with quantitative supplementation;

$>$ Interactive or equal status design.

The difference between these and mixed methods research is that multi-methodological researches were usually anchored on the same epistemological foundations of either positivism or interpretivism. The rationale is to take the best of the worlds of positivism and interpretivism. That meant giving the more-efficient and compelling predictive power of quantitative data and enriching it with the indepth contextualized natural and richer insight of qualitative data (Cohen, Manion and Morrison, 2011). Mixed methods research is differentiated from this by being existential and transformative.

\section{What is Mixed Methods Research?}

According to Creswell, et al (2014); mixed methods research is one that:

$>$ focuses on research questions that call for real-life contextual understanding, multi-level perspectives, and cultural influence;

$>$ employs rigorous quantitative research assessing magnitude and frequency of constructions and rigorous qualitative research exploring meanings and understandings of constructs;

$>$ utilizes multiple methods;

$>$ intentionally integrates or combines these methods to draw on the strength of each; and

$>$ frames the investigation within philosophical and theoretical positions.

The Philosophical Foundations of Mixed Methods Research 
In order to draw out the philosophical foundations of mixed methods research, we present below a tabulation which contrasts it with the philosophical foundations of positivism and interpretivism. This will enable the reader to conclude whether or not mixed methods research represents a fourth or third paradigm in social science research.

Tables 1: Philosophical Foundations of Positivism, Interpretativism and Mixed Methods

\begin{tabular}{|l|l|l|l|}
\hline $\begin{array}{l}\text { Aspects } \\
\text { (Dimensions) }\end{array}$ & Positivism & Interpretivism & Mixed methods \\
\hline $\begin{array}{l}\text { Ontological } \\
\text { status of } \\
\text { Phenomena }\end{array}$ & Objective & $\begin{array}{l}\text { Socially constructed } \\
\text { existents in the } \\
\text { consciousness of actors } \\
\text { in the socio-cultural space } \\
\text { and time }\end{array}$ & $\begin{array}{l}\text { Objective existents and } \\
\text { socially constructed } \\
\text { cultural existents }\end{array}$ \\
\hline Truth & $\begin{array}{l}\text { Correspondence } \\
\text { (out-there) }\end{array}$ & $\begin{array}{c}\text { Coherence with } \\
\text { actors' consciousness in } \\
\text { the socio-cultural space } \\
\text { and time }\end{array}$ & $\begin{array}{l}\text { Partly correspondence } \\
\text { and partly coherence }\end{array}$ \\
\hline Reality & $\begin{array}{l}\text { Directly } \\
\text { apprehendable by } \\
\text { the senses; single } \\
\text { reality }\end{array}$ & $\begin{array}{l}\text { Subjective and socially } \\
\text { constructed but not directly } \\
\text { apprehendable; multiple } \\
\text { versions of reality }\end{array}$ & $\begin{array}{l}\text { Partly directly } \\
\text { apprehendable and } \\
\text { partly subjectively } \\
\text { apprehendable as they } \\
\text { reside in the } \\
\text { consciousness of actors } \\
\text { and in the socio-cultural } \\
\text { space and time and } \\
\text { existential conditions }\end{array}$ \\
\hline Epistemology & Scientific, objectiv & $\begin{array}{l}\text { Subjective and } \\
\text { existential }\end{array}$ & $\begin{array}{l}\text { Goodness-o'f-fit } \\
\text { pragmatism for solution } \\
\text { to existential challenges. } \\
\text { Transformative. }\end{array}$ \\
\hline
\end{tabular}




\begin{tabular}{|c|c|c|c|}
\hline Meaning & $\begin{array}{l}\text { Externally observable } \\
\text { and definitional }\end{array}$ & $\begin{array}{l}\text { Resides both in actors' } \\
\text { consciousness and hi the } \\
\text { socio-cultural space and } \\
\text { time as generated activated } \\
\text { and manifested in social } \\
\text { interaction. }\end{array}$ & $\begin{array}{l}\text { Resides both in actors' } \\
\text { consciousness and in } * \text { the } \\
\text { socio-cultural space and time } \\
\text { and manifested in the externally } \\
\text { measurable and internally } \\
\text { experienced existential } \\
\text { conditions of actors }\end{array}$ \\
\hline Value & $\begin{array}{l}\text { Externally observable } \\
\text { and definable }\end{array}$ & $\begin{array}{l}\text { Comprehended internally } \\
\text { in actors consciousness } \\
\text { but also simultaneously } \\
\text { manifested and recreated in } \\
\text { interactions in the socio- } \\
\text { cultural space and time }\end{array}$ & $\begin{array}{l}\text { Comprehended in the context } \\
\text { of the existential conditions of } \\
\text { actors. }\end{array}$ \\
\hline $\begin{array}{l}\text { Main } \\
\text { questions } \\
\text { answered }\end{array}$ & What & Why, how & What, why and how. \\
\hline $\begin{array}{l}\text { What research } \\
\text { does or provide }\end{array}$ & $\begin{array}{l}\text { Explanation } \\
\text { Generally and pattern } \\
\text { regularity }\end{array}$ & $\begin{array}{l}\text { Understanding contextual } \\
\text { complexity }\end{array}$ & $\begin{array}{l}\text { Explanation and } \\
\text { understanding } \\
\text { Patterned regularity in } \\
\text { contextual complexity }\end{array}$ \\
\hline Perspective & Outsider & Insider & Outsider and insider \\
\hline Focus & Constituent parts & Whole & $\begin{array}{l}\text { Parts and whole as manifested } \\
\text { in existential conditions }\end{array}$ \\
\hline
\end{tabular}

Pragmatism as an epistemology

Pragmatism is the core epistemology of mixed methods research and the following are its main dimensions:

$>$ Practical rather than idealistic;

$>$ Argues that there are both singular and multiple versions of truth and reality;

$>$ Matter-of-fact approach to life;

$>$ Oriented to the solution of practical problems in the practical world;

$>$ Prefers utility, practical consequences and outcomes and heurism to the singular pursuit of the most accurate representation of reality;

$>$ Methodologically eclectic based on the criteria of fitness-for-purpose and applicability.

\section{Does what we have spelt out above constitute a new paradigm?}

A paradigm has been defined as a set of assumptions, concepts, values and practices that constitute a way of viewing reality for the community that shares them, especially in an intellectual discipline. (Farlex the Free Dictionary). In the philosophy of science, it is defined as a. very general conception of the nature of scientific endeavour within which a given enquiry is undertaken. 
Mixed methods research has been described as constituting a new third paradigm, the transformative paradigm. For example, the journal of mixed methods (2007) asserts: The transformative paradigm with its associated philosophical assumptions provides a framework for addressing inequality and injustice in society using culturally competent mixed methods strategies.

Transformative research challenges current understanding or provides pathways to new frontiers by being predicated on new ideas or tools and producing discoveries that radically change engineering concept or educational practice or leads to the creation of a new paradigm. The idea of transformative research derives from Thomas Kuhn's notion of scientific revolutions where one scientific paradigm is overturned for another.

The transformative paradigm of mixed methods research is based on the belief that knowledge is not neutral; it is influenced by human interests. Knowledge, it asserts reflects power and social relationships within society. Translated in the context of research, this paradigm recognises that realities are constructed and shaped by social, political, cultural, economic and racial or ethnic values. The consequences of this are that power and privilege are important determinants as to which reality will be dominant in a research context. This derives from the recognition that the basic ontological and epistemological assumptions held by any researcher will shape the kind of methods adopted. It is also transformative in that it provides a mechanism for addressing the complex settings that can provide a basis for social change.

Conclusively, we can say that the transformative paradigm of mixed methods research represents a world view and its accompanying philosophical assumptions (as spelt out in the tabulation above) that emerged from the work of scholars from diverse ethnic and racial groups, people with disabilities and feminists working in contested territory laden with pluralistic values and associated real-life implications for resources allocation.

\section{References}

AAAS (2008) Advancing Research in Science and Engineering (ARISE): Investing in EarlyCareer Scientists and High-Risk-High-Reward Research. Cambridge, MA: American Academy of Arts and Sciences. Available at http://wmv.amacad.org/arisefolder/ariseReport.pdf

Ardeh, L. B. Jr. (2007) Transformative Research: The Artistry and Alchemy of the $21{ }^{\text {st }}$ Century, Paper delivered to the Texas Academy of Medicine, Engineering and Science on Jan. 4, 2007. Available at http://www.nsf.gov/news/speeches/bement/07/alb0701Q4-texas.jsp 
Austin, F. C. (2008) 'High-Risk, High-Reward Research Demonstration Project'. Presentation given to the NIH Council of Councils. Available at http://dpcpsi.gov/pdf/coc-112008-AustinHRHR.pdf

Cohen, L., Manion, L., and Morrison, K. (2011) Research Methods in Education, New York, Routledge.

Creswell, J. W., et al (2014). Best Practices for Mixed Methods Research in the Health Sciences.

Gautam, S. (2013) Transformative Research Paradigm In Orality and Literacy, Downloaded: Methodspace.com on Dec. 18, 2014.

Igun, U. A. (2011). Methodological Foundations of Social Science, Benin City, Ethiope Publishing Corporation.

Mertens, D. M. (2007). Transformative paradigm: Mixed Methods and Social Justice, Journal of Mixed Methods Research, 1 .(3), pp. 212-225. http://eric.ed.gov/?id=EJ804528mmr.sagepub.com/ content/1/3/212 website: http://sagepub.com

Mertens, D. M. Transformative Paradigm. SAGE Research Methods Encyclopedia Entry

United States National Science Foundation (2007) Enhancing Support of Transformative Research at the National Science Foundation, 2007 Report.

Wikipedia.org/wiki/Transformative Research; 2014.

Wright, V. (1975). Explanation and Understanding, London: Routledge and Kegan Paul. 